\title{
The Relationship between Capital Structure and Performance in Gulf Countries Banks: A Comparative Study between Islamic Banks and Conventional Banks
}

\author{
Abdelrhman Ahmad Meero ${ }^{1}$ \\ 1 Associate Professor in Finance and Banking, College of Business Adminstrtion, Finance and Accounting \\ Department, Kingdom University, Bahrain \\ Correspondence: Abdelrhman Ahmad Meero, College of Business Adminstation, Kingdom University, PO Box: \\ 40434, Kingdom of Bahrain. Tel: 973-1330-0920. E-mail: a.meero@ku.edu.bh
}

Received: September 16, 2015

Accepted: October 30, $2015 \quad$ Online Published: November 25, 2015

doi:10.5539/ijef.v7n12p140

URL: http://dx.doi.org/10.5539/ijef.v7n12p140

\begin{abstract}
This paper mainly has two objectives: the first one is to identify the similarity of capital structure between Islamic and Conventional banks; Second objective is to detect the relationship between capital structure variables and performance of Islamic and Conventional Banks in Gulf Countries (GC). This investigation has been performed on a sample of $16 \mathrm{GC}$ Banks (8 Islamic Banks and 8 Conventional Banks) for the period 2005-2014. ROE (return on equity) and ROA (return of asset) have been used as performance measures. Total debt to total assets, Equity to total assets, Debt to equity ratios have been used as capital structure measures. Size of the bank has been considered as dependent variable to identify its relationship with bank performance. Data collected were analyzed by using SPSS software. The results of the research indicate a similarity of capital structure of Islamic banks and Conventional banks in Gulf Countries. ROA as performance measurement has a significant negative relationship with financial leverage and a positive relationship with equity to assets ratio. This relationship is identified at Islamic banks, Conventional banks and all the banks of the sample. Bank size has a positive relationship with ROA and ROE as performance measures in Islamic and Conventional banks.
\end{abstract}

Keywords: Islamic banks, Conventional banks, return on equity, return on assets, capital structure, bank size, Gulf countries

\section{Introduction}

Relationship between capital structure and firm performance is widely discussed and tested in the literature review. In spite of the numerous studies of this subject, the effect of capital structure on firm performance stills the most perplexing issues in corporate finance literature (Brounen \& Eichholtz, 2001). The pioneer researches in capital structure and performance have been started early with the works of Lintner (1956), Hirshleifer (1958) and Modigliani and Miller (1958). These studies have been followed by other researches which focused on corporate capital structure and its impact on firm's performance such as the works of Modigliani and Miller (1963); Jensen and Meckling (1976); Miller (1977); Myers (1977); Titman and Wessels (1988); Roden and Lewellen (1995); Champion (1999), Ghosh et al. (2000); Hadlock and James (2002); Margaritis and Psillaki (2010); Salim and Yadev (2012); Tianyu (2013).

In spite of this heavy literature review related to the performance implications of capital structure choices in developed countries, it stills at earlier stage in the developing countries (e.g. Arab Countries, African Countries and Gulf area). For that reason, this paper aims to compare the similarity of capital structure between Islamic banks and Conventional banks in Gulf countries (GC). It aims to detect the significance of the relationship between capital structure and banks performance.

The sample of study contains 16 banks from all the Gulf Countries, 8 Islamic banks and 8 Conventional banks. Analyzed data are related to the period 2005-2014. Source of the data is Thomson One - Business School Edition. Microsoft Excel 2010 and SPSS 16.0 (Statistical Package for the Social Sciences) have been used to detect the similarity of capital structure and to test the significance of the relationship between performance and capital structure variables.

Following the section 1: introduction, this paper is organized into five more sections as follows: section 2 
presents the Literature Review related to the study, while section 3 is assigned to the formulation of the research hypotheses. Data, Model Specification, and Methodology are detailed in section 4. Findings and Hypotheses Testing are illustrated in section 5. Finally, section 6 is assigned to the concluding remarks of the study.

\section{Literature Review}

The theoretical framework of Capital structure theory was presented first by Modigliani and Miller (1958) who studied the changes of firm's value through changing its capital structure. Several hundreds of research papers were written trying to find the effect of capital structure on firm's performance. Two famous theories of financing decision-making have dominated the related literature, which are the static trade-off theory and the pecking order theory.

\subsection{The Static Trade-Off Theory}

Trade-off theory assumes that capital structure moves towards an optimum leverage which is determined by balancing the corporate tax savings merit of debt and the costs of financial distress. According to this theory, capital structure choices are determined by a trade-off between the benefits and costs of debt (Kraus \& Litzenberger, 1973). As explained by many researchers, optimal capital structure of organizations involves the tradeoff among the bankruptcy costs and agency costs, the effects of corporate and personal taxes (Jensen and Meckling,1976), bankruptcy costs, tax benefits, and agency costs related to asset substitution (Myers, 1977), and overinvestment (Jensen, 1986; Stulz, 1990). The trade-off hypothesis assumes a positive relationship between profitability and leverage because low profitability may increase bankruptcy risk (Kaya \& Kimura, 2011).

Different studies in different markets confirm the hypothesis of the trade-off theory. Yuanxin, and Zhuang (2009) studied the listed IT companies in Shanghai Stock Exchange and they found a positive correlation between capital structure and performance. Petersen and Rajan (1994) found a significantly positive relationship between profitability and debt ratio. Bingbing (2010) found a positive correlation between capital structure and performance. In China's power industry, Junhua (2011). showed a positive correlation between capital structure and corporate performance. Shlash, AlBakom, and Alouf (2006) studied Jordanian public shareholding companies listed on Amman Stock Exchange for the period (1997-2001). The study found that there is a positive significant statistical relationship between financial structure and prior debt ratio. San and Hang (2011) confirm this positive relationship in construction companies in Malaysia. This positive relationship is confirmed by the study of Nirajini and Priya (2013) in listed trading companies in Sri Lanka. This result is aligned with the findings of Abu Rub (2012) in listed companies in Palestinian Security exchange. Other studies support this fact such as the study of Frank and Goyal (2003) and Hadlock and James (2002). Pratomo and Ismail (2006), that tested the impact of capital structure on banks performance in Malaysian banks where the findings showed that higher leverage is associated with higher profit efficiency in banks. Siddiqui and Shoaib (2011) found positive impact of leverage on performance in Pakistan banks. Berger and Di Patti (2000) indicated the positive association between leverage and bank performance. Champion (1999) concluded that companies can use more debt to enhance their financial performance because of debts' capability to cause managers to improve productivity to avoid bankruptcy. Abor (2005) found a significantly positive relationship between total debt and profitability.

Roden and Lewellen (1995) used a sample of 48 U.S. firms for the period 1981-1990 and found a positive relation between profitability and capital structure. In their researches Ghosh et al. (2000) and Hadlock and James (2002) concluded that highly profitable firms use high-level of debts. Margaritis and Psillaki (2010) studied a sample of French firms during the period 2003-2005 and observed a significant positive relation between leverage and firm's performance. Using panel data consisting of 257 South African firms over the period 1998 to 2009, Samuel (2013) investigated the relationship between capital structure and firm performance. He found a positive and significant relation between financial leverage and firm's performance. In Tehran Stock Exchange, Aliakbar, Seyed, and Pejman (2013) found either a significant positive link between capital structure and firm performance.

Other different studies such as: Ghosh et al. (2000); Hadlock and James (2002); Frank and Goyal (2003), Berger and Bonaccorsi (2006), found a positive relationship between capital structure and firm's performance

\subsection{The Pecking Order Theory}

Founders of the pecking order theory Myers and Majluf (1984) and Myers (1984) assume that firms issue first internal funds, debt, and then equity. They argue their result by the existence of costs of issuing risky securities, because of either asymmetric information (Myers, 1984; Myers \& Majluf, 1984) or managerial optimism (Heaton, 2002). This conclusion was confirmed by (Gungoraydinoglu \& Öztekin, 2011) and Drobetz et al. 
(2013). There is no concept of target capital structure for a firm in the pecking order theory which exists in the trade-off theory (Dang, 2013). According to Watson and Head (2007), the pecking order theory goes in opposition to the idea of firms having a distinctive mixture of debt and equity finance which minimizes their cost of capital. The explanation provided by Myers for the pecking order theory is based on the information asymmetry assumption where firm insiders have more information than outsiders (Chakroborty, 2010). According to the pecking order theory, firms with higher profitability will prefer internal financing to debt and hence a negative relationship is expected between profitability and leverage theory (Rajan \& Zingales, 1995; Fama \& French, 2002; Delcoure, 2007; Daskalakis \& Psillaki, 2008; Chakraborty, 2010; Kayo \& Kimura, 2011; Joeveer, 2013; Chakraborty, 2013; Dang, 2013).

Empirical evidences supporting the negative relationship between capital structure and firm's performance have been presented by Barton et al. (1989), Michael, Chittenden, and Poutziouris (1999), Mishra and McConaughty (1999), Jordan, Lowe, and Taylor (1998), Chittenden, Hall, and Hutchinson (1996) all support a negative relationship between profitability and capital structure. In China, Jesen, Solberg, and Zorn (1992) and Li Jiajuan (2010) showed negative relationship between the business performance and debt ratio. Al-Farisi and Hendrawan (2012) studied the effect of capital structure on the performance of Islamic banks in comparison with conventional banks in Indonesia. The study found that the ownership percentage had a negative impact on performance in both conventional and Islamic banks.

Other researches have demonstrated the existence of negative impact of capital structure on firm performance such as Ebaid (2009) in listed Egyptian firms, Chakraborty (2010) in India, Karadeniz et al. (2009) in Turkish lodging companies and Huang and Sang (2006) in China. Krishnan and Moyer (1997) found a negative and significant impact of total debt to total equity (TD/TE) on Return on Equity (ROE). Gleason, Mathur and Mathur, (2000) found that firms capital structure has a negative and significant impact on firms performance measures return on assets (ROA). Toraman et al. (2013) investigated the effects of capital structure decisions on firms' profitability in manufacturing sector in Turkey. Research results showed that short term liabilities to total assets and long term liabilities to total assets have a negative relationship with the ROA as performance indicator. Chinaemerem and Anthony (2012) investigated the impact of capital structure on financial performance of Nigerian firms using a sample of thirty non-financial firms listed on the Nigerian Stock Exchange. The result demonstrated that a firm's capital structure has a significantly negative impact on the firm's financial performance.

Salim and Yadav (2012) studied the relationship between capital structure and firm performance on 237 Malaysian companies listed in Bursa Malaysia Stock Exchange. Research results demonstrated a negative correlation between the two variables. Soumadi and Hayajneh (2011) investigated the effect of capital structure on the performance of the public Jordanian firms listed in Amman stock market. Study results revealed that capital structure is associated negatively and statistically with firm performance. In addition, the study found out that there was no significant difference to the impact of the financial leverage between high financial leverage firms and low financial leverage firms on their performance.

Cassar and Holmes (2003) find a negative relationship between profitability and both long-term debt and short-term debt ratios. Rajan and Zingales (1995) and Wald (1999) also confirm a significantly negative correlation between profitability and leverage. Salehi and Biglar (2009) find that several measures of financial performance have negative relationship with financial leverage.

In banking sector, negative relationship between bank performance and capital structure has been found by Berger and Bouwman (2013), Adbabi and Abu-Rub (2012) and Victor and Badu, (2012). Amidu (2007) investigate the determinants of capital structure of banks in Ghana and found a significantly negative association between total debt and profitability.

\subsection{Firm Size and Performance}

Examining the literature review, we found important researches testing the relationship between firm size and performance. Studies based upon economies of scale theory argued that size has a positive effect on performance by inducing economies of scale, reflected by the fact that large firms take the advantage of economies of scale in reducing the costs of operations (Bashir, 1999; Said, 2012). Rossi et al. (2005) found that larger banks have better performance and better control on the cost side and are more capable of exploiting economies of scale. Muritala (2012) found that firm size is positively related to a firm's performance.

In banking sector, researches demonstrate positive relationship between bank size and performance. Such literature includes the studies of Berger, Hunter and Timme (1993), Miller and Noulas (1996), Girardone, Molyneux and Gardener (2004), Yudistira (2004), Hassan (2005), Rossi, Schwaiger and Winkler (2005), Delis 
and Papanikolaou (2009), Srairi (2010) and Siddiqui and Shoaib (2011).

Contrariwise, Rajan and Zingales (1995) found a negative relationship between profitability and size of the firm. According to Nigmonov (2010), the effect of size can be negative for banks that are extremely large because of bureaucracy. As a result, some studies find a negative relationship between bank size and performance (Fuentes \& Vergara, 2003; El Moussawi \& Obeid, 2011).

\section{The Hypotheses of the Study}

The literature review presented previously showed the importance of the research objectives of this paper. Researchers used in their studies certain variables as measures of firm's performance and other variables as measures of capital structure. In this study we have chosen ROA and ROE as performance measures and total debt to total assets, equity to total assets, debt to equity ratio and size as measures of capital structure. These variables have been used by previous researches as it is mentioned below:

ROE: Abor (2005), Amjed (2007), Shubite and Alsawalhah (2012).

ROA: Salawu (2009), Gill et al. (2011), This variable has been previously used by Guney et al. (2010), Cohu et al. (2011), Hall (2011), Chen et al. (2012) Fosu (2013).

ROE + ROA: Saeedi, Mahmoodi (2011), Ramachandran, Candasamy (2011), Pratheepkanth (2011), Abu-Rub (2011).

As capital structure variables: Total debt to total assets, Equity to total assets, Debt to equity ratio have been used by Manos et al. (2007), Guney et al. (2010), Papaa and Spicial (2011), Bei and Wijewardanab (2012), Park and Jang (2013), Fosu (2013), Kipesha and James (2014), Yisau. (2014), Berger and Di Patti (2006), Siddiqui and Shoaib (2011), Victor and Badu, (2012), Taani, (2013), and Chechet and Olayiwola, (2014).

The present study measures the size of banks by using the natural logarithm of total assets. This is similar to the studies of Bashir (1999), Milbourn, Boot and Thakor (1999), Gjirja (2003), Hassan (2005), Rossi et al. (2005), Altunbas et al. (2007) and El Moussawi and Obeid (2011).

These previous explanations allow us to use the following variables to study the effect of capital structure on bank performance.

Capital structure variables: Total debt to total assets, Equity to total assets, Debt to equity.

Bank performance variables: ROE: Return on Equity and ROA: Return on Assets.

To achieve the goals of this research similarity test of capital structure between Islamic and conventional banks has been done first then the effect of the capital structure on the performance of the banks has been tested. For that matter the study uses the following hypothesis:

\section{1) Similarity of capital structure}

H0: Islamic Banks and Conventional Banks have similar capital structure.

H1: Islamic Banks and Conventional Banks have different capital structure.

2) Capital structure and performance of banks in Gulf Countries (GC)

H0: capital structure doesn't affect GCC banks performance.

H1: capital structure affects GCC banks performance.

3) Capital structure and performance of Islamic Banks in Gulf Countries (GC)

H0: capital structure doesn't affect Islamic banks performance in GC.

H1: capital structure affects Islamic banks performance in GC.

\section{4) Capital structure and performance of Gulf banks}

H0: capital structure doesn't affect GC conventional banks performance.

H1: capital structure affects GC conventional banks performance.

The study population consists of all banks operating in Gulf Countries (GC). The sample of the study covers all the GC and contains 8 Islamic banks and 8 conventional banks. Table 1 presents the sample of the study: 
Table 1. The sample of the study

\begin{tabular}{lll}
\hline & Bank & Country \\
\hline $\mathbf{1}$ & ABU DHABI COMMERCIAL BANK & United Arab Emirates \\
$\mathbf{2}$ & ABU DHABI ISLAMIC BANK & United Arab Emirates \\
$\mathbf{3}$ & AHLI UNITED BANK KW & Kuwait \\
$\mathbf{4}$ & ALRAJHI BANKING AND INVESTMENT CORP SJS & Kingdom of Saudi Arabia \\
$\mathbf{5}$ & ALBARAKA BANKING GROUP BSC BH & Bahrain \\
$\mathbf{6}$ & BANK MUSCAT & Oman \\
$\mathbf{7}$ & COMMERCIAL BANK OF QATAR & Qatar \\
$\mathbf{8}$ & KUWAIT FINANCE HOUSE & Bahrain \\
$\mathbf{9}$ & NATIONAL BANK OF BAHRAIN BSC & Bahrain \\
$\mathbf{1 0}$ & NATIONAL BANK OF KUWAIT & Kuwait \\
$\mathbf{1 1}$ & NATIONAL BANK OF OMAN LIMITED & Oman \\
$\mathbf{1 2}$ & QATAR INTERNATIONAL ISLAMIC BANK & Qatar \\
$\mathbf{1 3}$ & QATAR ISLAMIC BANK & Qatar \\
$\mathbf{1 4}$ & QATAR NATIONAL BANK & Qatar \\
$\mathbf{1 5}$ & RIYAD BANK & Kingdom of Saudi Arabia \\
$\mathbf{1 6}$ & SAMBA FINANCIAL GROUP & Kingdom of Saudi Arabia \\
\hline
\end{tabular}

\section{Data, Model Specification, and Methodology}

To investigate the effect of capital structure on GC banks performance, this study used at the first stage T test analysis to examine the similarity of capital structure between Islamic banks and Conventional banks at Gulf Countries. Then correlation analysis has been used to investigate the relationship between capital structure and banks performance. Data from 2005 to 2014 has been used to test the hypothesis of the research. Balance sheets and income statements of the Sample have been analyzed by using Microsoft Excel 2010. SPSS 16.0 (Statistical Package for the Social Sciences) has been used to test the statistical relationship between variables.

In this section of the paper, the similarity of capital structure is tested in the paragraph (4.1). Then the relationship between capital structure and performance of Gulf banks is evaluated in (4.2). The relationship between capital structure and performance of Islamic banks in Gulf Countries is evaluated in (4.3). (4.4) is assigned to test the relationship between capital structure and performance of Conventional Bank in Gulf Countries.

\subsection{Similarity of Capital Structure}

This part of the paper aims to identify if the conventional banks and Islamic banks have similar or different capital structure. As previously introduced and discussed, variables of capital structure are:

$>$ Debt to total assets

$>$ Debt-equity ratio (DER)

$>$ Total equity to total assets

$>$ Size: The natural logarithm of total assets.

\subsubsection{Data Analysis}

SPSS software is used to analyze the data. For examining the similarity of capital structure between Islamic and conventional banks, T- test has been used. Four variables have been used to verify the similarity of Capital structure: Debt to assets ratio, Debt to Equity ratio, Equity to assets ratio, Bank Size.

\subsubsection{Variables Analysis}

T-test analysis, at $95 \%$ confidence interval, has been used to explore the difference in Debt to equity ratio between Islamic and Conventional banks. Data of the sample has been put to SPSS independent sample test has been done. Result of the analysis is presented in the two tables below:

Table 2. Group statistics

\begin{tabular}{lccccc}
\hline & Bank & N & Mean & Std. Deviation & Std. Error Mean \\
\hline \multirow{2}{*}{ DebtoEquity } & Islamic & 96 & 6.7210227 & 2.40529553 & .24548945 \\
& Conv & 96 & 6.5781488 & 1.93101788 & .19708369 \\
\hline
\end{tabular}


Table 3. Independent samples test

\begin{tabular}{|c|c|c|c|c|c|c|c|c|c|}
\hline & $\begin{array}{r}\text { Levene's T } \\
\text { Equality of V }\end{array}$ & $\begin{array}{l}\mathrm{t} \text { for } \\
\text { iances }\end{array}$ & & & & t-test for Equali & y of Means & & \\
\hline & & & & & Sig. & Mean & Std. Error & $\begin{array}{r}95 \% \text { Confic } \\
\text { of the I }\end{array}$ & $\begin{array}{l}\text { ce Interval } \\
\text { erence }\end{array}$ \\
\hline & $\mathrm{F}$ & Sig. & $\mathrm{t}$ & df & (2-tailed) & Difference & Difference & Lower & Upper \\
\hline $\begin{array}{l}\text { Deb to Equity Equal } \\
\text { variances assumed }\end{array}$ & 8.658 & .004 & .454 & 190 & .650 & .14287394 & .31481272 & -.47810302 & .76385090 \\
\hline $\begin{array}{l}\text { Equal variances not } \\
\text { assumed }\end{array}$ & & & .454 & 181.518 & .650 & .14287394 & .31481272 & -.47828906 & .76403693 \\
\hline
\end{tabular}

As Levene's test has sig value less than 0.05 then the results of the analysis is to be read from the bottom row. The sig (2-tailled) value related to our analysis is 0.65 which is greater than 0.05 which indicates that there is no statistically significant difference between the capital structure of Islamic and conventional banks expressed in Debt to Equity ratio.

The $\mathrm{T}$ test group has been done for the other variables and the table below resumes the result of the analysis.

Table 4. T test analysis for $95 \%$ confidence level

\begin{tabular}{lccl}
\hline Variable & $\begin{array}{c}\text { Levene's test sig } \\
\text { value }\end{array}$ & $\begin{array}{c}\text { sig (2-tailled) } \\
\text { value }\end{array}$ & $\begin{array}{c}\text { Results of the similarity of capital structure between } \\
\text { the Islamic and Conventional banks }\end{array}$ \\
\hline Debt-equity ratio (DER) & $\mathbf{. 0 0 4}$ & $\mathbf{. 6 5 0}$ & no statistically significant difference \\
Debt to total assets & $\mathbf{. 0 3}$ & $\mathbf{. 5 6 4}$ & no statistically significant difference \\
Total equity to total assets & $\mathbf{. 0 0 4}$ & $\mathbf{. 6 4 2}$ & no statistically significant difference \\
Size & $\mathbf{. 0 0 6}$ & $\mathbf{. 7 2 9}$ & no statistically significant difference \\
\hline
\end{tabular}

Results of $\mathrm{T}$ test analysis of all the variables indicate that there is no statistically significant difference between the capital structure of Islamic and Conventional banks

\subsection{Capital Structure and Performance of Gulf Banks}

The objective of this part of the paper is to test the relationship between capital structure variables and performance variables of Gulf banks. To achieve the objective correlation analysis has been done to the data of the banks sample. Table 5 shows the descriptive statistics for dependent and independent variables and Table 6 presents the results of correlation analysis.

Table 5. Descriptive statistics

\begin{tabular}{lccc}
\hline & Mean & Std. Deviation & $\mathrm{N}$ \\
\hline ROE & .1536691 & .08304664 & 192 \\
ROA & .0220340 & .01352441 & 192 \\
Debttototass & .8461688 & .11369482 & 192 \\
DebtoEquity & 6.6495858 & 2.17654814 & 192 \\
Equitoasset & .1411006 & .03979460 & 192 \\
BankSize & 9.8879367 & 1.73862384 & 192 \\
\hline
\end{tabular}

Note. Debttototass: Debt to assets ratio, DebtoEquity: Debt to Equity ratio, Equitoasset: Equity to assets ratio, BankSize: Bank Size.

Table 6a below shows the correlation matrix of capital structure variables and ROA. Results indicate that the relationship is negatively significant between ROA and leverage variables (Debt to assets and Debt to equity). ROA is positively related to the size and to the equity to assets ratio. 
Table 6a. Correlations between capital structure variables and ROA GC banks

\begin{tabular}{llccccc}
\hline & & ROA & Debttototass & DebtoEquity & Equitoasset & BankSize \\
\hline ROA & Pearson Correlation & 1 & & & & \\
Debttototass & Pearson Correlation & $-.354^{*}$ & 1 & & & \\
DebtoEquity & Pearson Correlation & $-.508^{*}$ & $.392^{*}$ & 1 & 1 & .083 \\
Equitoasset & Pearson Correlation & $.568^{*}$ & $-.464^{*}$ & $-.921^{*}$ & -.016 & .083 \\
BankSize & Pearson Correlation & $.213^{*}$ & .057 & & & 1 \\
\hline
\end{tabular}

*. Correlation is significant at the 0.05 level (1-tailed).

Table $6 \mathrm{~b}$ presents the correlation matrix between ROE and capital structure variables. Analysis results show a negative significant relationship between ROE and debt to total assets ratio while no significant relationship between ROE and debt to equity and equity to assets. ROE is positively and significantly related to banks size.

Table 6b. Correlations between capital structure variables and ROE in GC banks

\begin{tabular}{llccccc}
\hline & & ROE & Debttototass & DebtoEquity & Equitoasset & BankSize \\
\hline ROE & Pearson Correlation & 1 & & & & \\
Debttototass & Pearson Correlation & $-.120^{*}$ & 1 & & & \\
DebtoEquity & Pearson Correlation & -.117 & $.392^{*}$ & 1 & 1 & \\
Equitoasset & Pearson Correlation & .107 & $-.464^{*}$ & $-.921^{*}$ & .083 & 1 \\
BankSize & Pearson Correlation & $.229^{*}$ & .057 & -.016 & .083 \\
\hline
\end{tabular}

*. Correlation is significant at the 0.05 level

\subsection{Capital Structure and Performance of Islamic Banks in GC}

This part of the paper is assigned to evaluate the relationship between capital structure variables and performance variables of Islamic banks in Gulf Countries (GC). Table below shows the descriptive statistics for dependent and independent variables of Islamic banks in GC.

Table 7. Descriptive statistics of Islamic banks variables

\begin{tabular}{lccc}
\hline & Mean & Std. Deviation & N \\
\hline ROA & .0232911 & .01586304 & 96 \\
ROE & .1581051 & .08483177 & 96 \\
Debttototass & .8509167 & .09407199 & 96 \\
DebtoEquity & 6.7210227 & 2.40529553 & 96 \\
Equitoasset & .1424413 & .04494146 & 96 \\
BankSize & 9.9314915 & 1.57293272 & 96 \\
\hline
\end{tabular}

Note. Debttototass: Debt to assets ratio, DebtoEquity: Debt to Equity ratio, Equitoasset: Equity to assets ratio, BankSize: Bank Size.

Table below (Table 8a) illustrates the correlation matrix of capital structure variables and ROA in GC Islamic banks. Results indicate that the relationship is negatively significant between ROE and Debt to equity. ROA is positively related to the size and to the equity to assets ratio.

Table 8a. Correlations between capital structure variables and ROA in GC Islamic banks

\begin{tabular}{llccccc}
\hline & & ROA & Debttototass & DebtoEquity & Equitoasset & BankSize \\
\hline ROA & Pearson Correlation & 1 & & & & \\
Debttototass & Pearson Correlation & -.154 & 1 & & & \\
DebtoEquity & Pearson Correlation & $-.575^{*}$ & .119 & 1 & & \\
Equitoasset & Pearson Correlation & $.661^{*}$ & -.099 & $-.933^{*}$ & 1 & .148 \\
BankSize & Pearson Correlation & $.226^{*}$ & .108 & -.119 & .198 & 1 \\
\hline
\end{tabular}

*. Correlation is significant at the 0.05 level.

Table $8 \mathrm{~b}$ presents the correlation matrix between ROE and capital structure variables in GC Islamic banks. Analysis results show a positive significant relationship between ROE and equity to assets ratio and bank size, while no significance relationship between ROE and other capital structure variables in GC Islamic banks. 
Table $8 \mathrm{~b}$. Correlations between capital structure variables and ROE in GC Banks

\begin{tabular}{llccccc}
\hline & & ROE & Debttototass & DebtoEquity & Equitoasset & BankSize \\
\hline ROE & Pearson Correlation & 1 & & & & \\
Debttototass & Pearson Correlation & -.119 & 1 & & & \\
DebtoEquity & Pearson Correlation & -.155 & .119 & 1 & 1 & 1 \\
Equitoasset & Pearson Correlation & $.204^{*}$ & -.099 & $-.933^{*}$ & .148 & 1 \\
BankSize & Pearson Correlation & $.257^{*}$ & .108 & -.119 & & \\
\hline
\end{tabular}

*. Correlation is significant at the 0.05 level.

\subsection{Capital Structure and Performance of Conventional Banks in GC}

The analysis of the relationship between capital structure and GC conventional banks' performance is presented in the Tables 9a, 9b and 9C. The first table presents the descriptive statistics of Conventional Banks variables.

Table 9a. Descriptive statistics of conventional banks variables

\begin{tabular}{lccc}
\hline & Mean & Std. Deviation & $\mathrm{N}$ \\
\hline ROA & .0207768 & .01062613 & 96 \\
ROE & .1492331 & .08142412 & 96 \\
Debttototass & .8509167 & .09407199 & 96 \\
DebtoEquity & 6.5781488 & 1.93101788 & 96 \\
Equitoasset & .1397598 & .03406644 & 96 \\
BankSize & 9.8443820 & 1.89723312 & 96 \\
\hline
\end{tabular}

Note. Debttototass: Debt to assets ratio, DebtoEquity: Debt to Equity ratio, Equitoasset: Equity to assets ratio, BankSize: Bank Size.

Table 9b shows the correlation matrix of capital structure variables and ROA in GC Conventional banks. Negative significant relationship has been noticed between ROA and debt to equity ratio in GC conventional banks. Meanwhile a positive and significant relationship has been noticed between ROA and equity to assets ratio and bank size.

Table 9b. Correlations between capital structure variables and ROA in GC Conventional banks

\begin{tabular}{llccccc}
\hline & & ROA & Debttototass & DebtoEquity & Equitoasset & BankSize \\
\hline ROA & Pearson Correlation & 1 & & & & \\
Debttototass & Pearson Correlation & -.118 & 1 & & & \\
DebtoEquity & Pearson Correlation & $-.405^{*}$ & $.228^{*}$ & 1 & & \\
Equitoasset & Pearson Correlation & $.388^{*}$ & $-.260^{*}$ & $-.908^{*}$ & 1 & .015 \\
BankSize & Pearson Correlation & $.215^{*}$ & .117 & .088 & .015 & 1 \\
\hline
\end{tabular}

*. Correlation is significant at the 0.05 level.

Table 9c presents the correlation matrix between ROE and capital structure variables in GC Conventional banks. Analysis results show a positive significant relationship between ROE and bank size. Results show also that there is no significant relationship between ROE and the other capital structure variables.

Table 9c. Correlations between capital structure variables and ROE in GC conventional banks

\begin{tabular}{llccccc}
\hline & & ROE & Debttototass & DebtoEquity & Equitoasset & BankSize \\
\hline ROE & Pearson Correlation & 1 & & & & \\
Debttototass & Pearson Correlation & -.022 & 1 & & & \\
DebtoEquity & Pearson Correlation & -.072 & $.228^{*}$ & 1 & 1 &. $.908^{*}$ \\
Equitoasset & Pearson Correlation & -.029 & $-.260^{* *}$ & .088 & .015 & 1 \\
BankSize & Pearson Correlation & $.205^{*}$ & .117 & & & \\
\hline
\end{tabular}

*. Correlation is significant at the 0.05 level. 


\section{Findings and Hypotheses Testing}

\subsection{Similarity of Capital Structure}

Results demonstrate the similarity of capital structure of Islamic and Conventional Banks in Gulf Countries. This similarity is clearly shown for all variables used in this research: Debt to assets, Debt to Equity ratio, Equity to assets ratio and Bank Size. Thus, there is no significant difference between capital structure of GC banks and the null hypothesis $\mathrm{H} 0$ is approved.

H1,0: Islamic Banks and Conventional Banks have similar capital structure.

\subsection{Capital Structure and Performance of Conventional Banks in GC}

Table 10 resumes the relationships between the banks performance and capital structure. ROA as performance measure is positively related to bank size and equity to assets ratio and negatively related to Debt to equity ratio. This result is valid in Conventional banks, Islamic banks and at the global level of all banks in GC. In the other hand, when ROE is the performance measure, the relationship with capital structure variables is positively significant with bank size in Conventional banks, Islamic banks and at the global level of all banks in GC. ROE relationship is positively significant also with equity to assets ratio in Islamic banks and it is negatively significant with Debt to assets ratio in Conventional banks.

Tables 10. Resume of all correlations analysis results

\begin{tabular}{clccc}
\hline \multirow{2}{*}{ Performance variable } & Capital structure variable & \multicolumn{3}{c}{ Significance of the relationship } \\
\cline { 3 - 4 } & & All Banks & Islamic & Conventional \\
\hline \multirow{2}{*}{ ROA } & Debt to assets & - & N/A & N/A \\
& Debt to Equity ratio & - & - & - \\
& Equity to assets ratio & + & + & + \\
& Bank Size & + & N/A & N/A \\
& Debt to assets & - & N/A & N/A \\
& Debt to Equity ratio & N/A & + & N/A \\
& Equity to assets ratio & N/A & + & + \\
& Bank Size & + & +
\end{tabular}

Note. -: Significant and negatively related, +: Significant and positively related, N/A: no Significant relationship.

Previous findings allow us to conclude that bank capital structure affect banks performance (ROA) in Gulf countries and the $\mathrm{H} 2,0$ is rejected and $\mathrm{H} 2,1$ is supported:

\section{H2,1: capital structure affects GCC banks performance.}

Findings either support the hypothesis of the capital structure effect on Islamic banks performance (ROA) which means supporting the hypothesis $\mathrm{H} 3,1$ and rejection of the hypothesis $\mathrm{H} 3,0$

\section{H3,1: capital structure affects Islamic banks performance in GC.}

Regarding the capital structure relationship and Conventional banks performance (ROA) relationship, results support the hypothesis $\mathrm{H} 4,1$ :

\section{H4,1: capital structure affects GC conventional banks performance.}

When the ROE is the bank performance measure, the relationship between bank performance and capital structure variables is not significant to the extent that we can accept or reject the hypothesis of the research. It is only significant

\section{Conclusions}

Results of the study demonstrate similarity of capital structure of Islamic banks and Conventional banks in Gulf Countries. Results found are similar to the findings of Siraj and Pillai (2012) which found this similarity between conventional banks and Islamic bank in GC. This similarity of capital structure could be the result of regulation system in Gulf Countries which controls the two types of banks by the same capital adequacy regulations. Similarity of Capital structure in our study is contrary with findings in previous researches (Jaffar \& Manarvi., 2011) in Pakistan banking sector. These different conclusions regarding the similarity of capital structure encourage interested researchers to do more investigations on this subject and especially in developing countries. 
ROA as performance measurement is negatively related to the financial leverage which is aligned with the results of Maksimovic and Titman (1991), Myers (1977) and Coricelli et al. (2012). This result is either aligned with the Standard pecking order theory and the findings of Rajan and Zingales (1995); Fama and French (2002); Delcoure (2007); Daskalakis and Psillaki (2008); Chakraborty (2010); Kayo and Kimura (2011); Joeveer (2013); Chakraborty (2013); Dang (2013).

ROA as performance measurement either has a positive relationship with equity to assets ratio. These findings seem to suggest that the more efficient banks use less leverage (more equity) compared to their peers. This result is aligned with the findings of Isik and Hassan, 2003; Staikouras and Wood, 2003; and Sufian and Habibullah, 2009.

Result analysis either demonstrates a positive relationship between performance and bank size in conventional and Islamic banks which is similar to the results of researches in banking sector conducted by Berger, Hunter and Timme (1993), Miller and Noulas (1996), Girardone, Molyneux and Gardener (2004), da Silva e Souza and Tabak (2002), Yudistira (2004), Hassan (2005), Rossi, Schwaiger, and Winkler (2005), Delis and Papanikolaou (2009), Srairi (2010), and Siddiqui and Shoaib (2011).

\section{References}

Abdabi, S., \& Abu-Rub, N. (2012). The effect of Capital Structure on the Performance of Palestian Financial Institutions. British Journal of Economics, Finance and Management Sciences, 3(2), 92-101.

Abiodun, B. Y. (2014). Triangulation Analysis of Capital Structure and Firms' Performance in Nigeria. International Proceedings of Economics Development and Research, 69-75.

Abor, J. (2005). The effect of capital structure on profitability: An empirical analysis of listed firms in Ghana. The Journal of Risk Finance, 6(5), 438-445. http://dx.doi.org/10.1108/15265940510633505

Abu Rub, N. (2012). Capital structure and firm performance: Evidence from Palestine stock exchange. Journal of Money, Investment and Banking, (23).

Al-Farisi, A., \& Hendrawan, R. (2012). Effect of Capital Structure on Banks Performance: A Profit Efficiency Approach Islamic and Conventional Banks Case in Indonesia. International Research Journal of Finance and Economics, (86).

Aliakbar, R., Seyed, H. S. N., \& Pejman, M. (2013). The relationship between capital structure decisions with firm performance: Comparison between big and small industries in firms listed at Tehran Stock Exchange. World of Sciences Journal, 1(9), 83-92.

Altunbas, Y., Carbo, S., Gardener, E. P., \& Molyneux, P. (2007). Examining the relationships between capital, risk and efficiency in European banking. European Financial Management, 13(1), 49-70. http://dx.doi.org/10.1111/j.1468-036X.2006.00285.x

Amidu, M. (2007). Determinants of capital structure of banks in Ghana: An empirical approach. Baltic Journal of Management, 2(1), 67-79. http://dx.doi.org/10.1108/17465260710720255

Amjed, S. (2007). The impact of financial structure on profitability: Study of Pakistan's Textile Sector. Management of International Business and Economic Systems, 440-450.

Antoniou, A., Guney, Y., \& Paudyal, K. (2008). The Determinants of Capital Structure: Capital Market-Oriented Versus Bank-Oriented İnstitutions. Journal of Financial and Quantitative Analysis, 43, 59-92. http://dx.doi.org/10.1017/S0022109000002751

Babalola, Y. A. (2012). The impact of corporate social responsibility on firms' profitability in Nigeria. European Journal of Economics, Finance and Administrative Sciences, 45(1), 39-50.

Barton, S. L., Hill, N. C., \& Sundaram, S. (1989). An empirical test of stakeholder theory predictions of capital structure. Financial Management, 36-44. http://dx.doi.org/10.2307/3665696

Bashir, M. (1999). Risk and Profitability Measures in Islamic Banks: The case of two Sudanese banks. Islamic Economic Studies, 6(2), 1-24.

Bei, Z., \& Wijewardana, W. P. (2012). Financial leverage, firm growth and financial strength in the listed companies in Sri Lanka. Procedia-Social and Behavioral Sciences, 40, 709-715. http://dx.doi.org/10.1016/j.sbspro.2012.03.253

Berger, A. N., \& Bouwman, C. H. (2013). How does capital affect bank performance during financial crises? Journal of Financial Economics, 109(1), 146-176. http://dx.doi.org/10.1016/j.jfineco.2013.02.008 
Berger, A. N., \& Di Patti, E. B. (2006). Capital structure and firm performance: A new approach to testing agency theory and an application to the banking industry. Journal of Banking \& Finance, 30(4), 1065-1102. http://dx.doi.org/10.1016/j.jbankfin.2005.05.015

Berger, A. N., Hunter, W. C., \& Timme, S. G. (1993). The efficiency of financial institutions: A review and preview of research past, present and future. Journal of Banking \& Finance, 17(2), 221-249. http://dx.doi.org/10.1016/0378-4266(93)90030-H

Bingbing, S., \& Li, Z. (2010). State-owned Holding Company Capital Structure and Corporate Performance Study. Journal of Accounting, (3).

Brounen, D., \& Eichholtz, P. (2001). Capital structure theory: Evidence from European property companies' capital offerings. Real Estate Economics, 29(4), 615-632. http://dx.doi.org/10.1111/1080-8620.00025

Cassar, G., \& Holmes, S. (2003). Capital structure and financing of SMEs: Australian evidence. Accounting and Finance, 43(2), 123-147. http://dx.doi.org/10.1111/1467-629X.t01-1-00085

Chakraborty, I. (2010). Capital structure in an emerging stock market: The case of India. Research in International Business and Finance, 24(3), 295-314. http://dx.doi.org/10.1016/j.ribaf.2010.02.001

Chakraborty, I. (2013). Does capital structure depend on group affiliation? An analysis of Indian firms. Journal of Policy Modeling, 35(1), 110-120. http://dx.doi.org/10.1016/j.jpolmod.2012.02.006

Champion, D. (1999). Finance: The joy of leverage. Harvard Business Review, 77(4), 19-22.

Chechet, I., \& Olayiwola. (2014). Capital Structure and Profitability of Nigeria Quoted Firms. The Agency Cost Theory Perspective. American International Journal of Social Science, 3(1), 139-158.

Chen, S., Wang, K., \& Li, X. (2012). Product market competition, ultimate controlling structure and related party transactions. China Journal of Accounting Research, (5), 293-306. http://dx.doi.org/10.1016/j.cjar.2012.11.001

Chinaemerem, O., \& Anthony, O. (2012). Impact of Capital Structure on the Financial Performance of Nigerian Firms. Arabian Journal of Business and Management Review, 1(12), 43-61. http://dx.doi.org/10.12816/0002231

Chittenden, F., Hall, G., \& Hutchinson, P. (1996). Small firm growth, access to capital markets and financial structure: Review of issues and an empirical investigation. Small Business Economics, 8(1), 59-67. http://dx.doi.org/10.1007/BF00391976

Coricelli, F., Driffield, N., Pal, S., \& Roland, I. (2012). When does leverage hurt productivity growth? A firm-level Analysisq. Journal of International Money and Finance, (31), 1674-1694. http://dx.doi.org/10.1016/j.jimonfin.2012.03.006

Dang, V. A. (2013). Testing capital structure theories using error correction models: Evidence from the UK, France and Germany. Applied Economics, 45(2), 171-190. http://dx.doi.org/10.1080/00036846.2011.597724

Daskalakis, N., \& Psillaki, M. (2008). Do country or firm factors explain capital structure? Evidence from SMEs in France and Greece. Applied Financial Economics, 18(2), 87-97. http://dx.doi.org/10.1080/09603100601018864

Delcoure, N. (2007). The determinants of capital structure in transitional economies. International Review of Economics \& Finance, 16(3), 400-415. http://dx.doi.org/10.1016/j.iref.2005.03.005

Delis, M. D., \& Papanikolaou, N. I. (2009). Determinants of bank efficiency: Evidence from a semi-parametric methodology. Managerial Finance, 35(3), 260-275. http://dx.doi.org/10.1108/03074350910931771

Drobetz, W., Gounopoulos, D., Merikas, A., \& Schröder, H. (2013). Capital structure decisions of globally-listed shipping companies. Transportation Research Part E: Logistics and Transportation Review, 52, 49-76. http://dx.doi.org/10.1016/j.tre.2012.11.008

Ebaid, E. I. (2009). The impact of capital-structure choice on firm performance: Empirical evidence from Egypt. The Journal of Risk Finance, 10(5), 477-487. http://dx.doi.org/10.1108/15265940911001385

El Moussawi, C., \& Obeid, H. (2011). Evaluating the productive efficiency of Islamic banking in GCC: A non-parametric approach. International Management Review, 7(1), 10-21.

Fama, E. F., \& French, K. R. (2002). Testing trade-off and pecking order predictions about dividends and debt. Review of Financial Studies, 15(1), 1-33. http://dx.doi.org/10.1093/rfs/15.1.1 
Fosu, S. (2013). Capital structure, product market competition and firm performance: Evidence from South Africa. The Quarterly Review of Economics and Finance, 53(2), 140-151. http://dx.doi.org/10.1016/j.qref.2013.02.004

Frank, M. Z., \& Goyal, V. K. (2003). Testing the pecking order theory of capital structure. Journal of Financial Economics, 67(2), 217-248. http://dx.doi.org/10.1016/S0304-405X(02)00252-0

Fuentes, R., \& Vergara, M. (2003, May). Explaining bank efficiency: Bank size or ownership structure? In Proceedings of the VIII Meeting of the Research Network of Central Banks of the Americas (pp. 12-14).

Ghosh, C., Nag, R., \& Sirmans, C. (2000). The pricing of seasoned equity offerings: evidence from REITs. Real Estate Economics, 28, 363-384. http://dx.doi.org/10.1111/1540-6229.00805

Gill, A., Biger, N., \& Mathur, N. (2011). The Effect of Capital Structure on Profitability: Evidence from the United States. International Journal of Management, 28(4), 3-15.

Girardone, C., Molyneux, P., \& Gardener, E. P. (2004). Analysing the determinants of bank efficiency: The case of Italian banks. Applied Economics, 36(3), 215-227. http://dx.doi.org/10.1080/0003684042000175334

Gjirja, M. (2003). Assessing the Efficiency Effects of Bank Mergers in Sweden-A Panelbased Stochastic Frontier Analysis. Department of Economics, Goteborg University.

Gleason, K. C., Mathur, L. K., \& Mathur, I. (2000). The interrelationship between culture, capital structure, and performance: Evidence from European retailers. Journal of Business Research, 50(2), 185-191. http://dx.doi.org/10.1016/S0148-2963(99)00031-4

Granger, C. W. (1969). Investigating causal relations by econometric models and cross-spectral methods. Econometrica: Journal of the Econometric Society, 424-438. http://dx.doi.org/10.2307/1912791

Gungoraydinoglu, A., \& Öztekin, Ö. (2011). Firm-and country-level determinants of corporate leverage: Some new international evidence. Journal of Corporate Finance, 17(5), 1457-1474. http://dx.doi.org/10.1016/j.jcorpfin.2011.08.004

Hadlock, C., \& James, C. (2002). Do banks provide financial slack? Journal of Finance, 57(3), 1383-1420. http://dx.doi.org/10.1111/1540-6261.00464

Hall, T. (2012). The collateral channel: Evidence on leverage and asset tangibility. Journal of Corporate Finance, (18), 570-583. http://dx.doi.org/10.1016/j.jcorpfin.2011.12.003

Hassan, M. K. (2005). The Cost, Profit and X-Efficiency of Islamic Banks. Paper Presented at the 12th ERF Annual Conference, December 19-21, Egypt.

Heaton, J. B. (2002). Managerial optimism and corporate finance. Financial Management, 33-45. http://dx.doi.org/10.2307/3666221

Hirshleifer, J. (1958). On the theory of optimal investment decision. The Journal of Political Economy, 329-352. http://dx.doi.org/10.1086/258057

Huang, G. (2006). The determinants of capital structure: Evidence from China. China Economic Review, 17(1), 14-36. http://dx.doi.org/10.1016/j.chieco.2005.02.007

Isik, I., \& Hassan, M. K. (2003). Efficiency, Ownership and Market Structure, Corporate Control and Governance in the Turkish Banking Industry. Journal of Business Finance and Accounting, 30(9\&10), 1363-1421. http://dx.doi.org/10.1111/j.0306-686X.2003.05533.x

Jaffar, M., \& Manarvi, I. (2011). Performance comparison of Islamic and Conventional banks in Pakistan. Global Journal of Management and Business Research, 11(1).

Jensen, G. R., Solberg, D. P., \& Zorn, T. S. (1992). Simultaneous determination of insider ownership, debt, and dividend policies. Journal of Financial and Quantitative Analysis, 27(2), 247-263. http://dx.doi.org/10.2307/2331370

Jensen, M. C. (1986). Agency costs of free cash flow, corporate finance, and takeovers. American Economic Review, 76(2), 323-339.

Jensen, M., \& Meckling, W. (1976). Theory of the firm: Managerial Behavior, Agency Costs and Ownership Structure. Journal of Financial Economics, 3, 305-360. http://dx.doi.org/10.1016/0304-405X(76)90026-X

Jõeveer, K. (2013). What do we know about the capital structure of small firms? Small Business Economics, 41(2), 479-501. http://dx.doi.org/10.1007/s11187-012-9440-1 
Jordan, J., Lowe, J., \& Taylor, P. (1998). Strategy and financial policy in UK small firms. Journal of Business Finance \& Accounting, 25(1-2), 1-27. http://dx.doi.org/10.1111/1468-5957.00176

Junhua, Z. (2011). Capital Structure and Corporate Performance. Journal of Accounting, (4), 78-80.

Karadeniz, E., Kandir, S. Y., Balcilar, M., \& Onal, Y. B. (2009). Determinants of capital structure: Evidence from Turkish lodging companies. International Journal of Contemporary Hospitality Management, 21(5), 594-609. http://dx.doi.org/10.1108/09596110910967827

Kayo, E. K., \& Kimura, H. (2011). Hierarchical determinants of capital structure. Journal of Banking \& Finance, 35(2), 358-371. http://dx.doi.org/10.1016/j.jbankfin.2010.08.015

Kipesha, E. F., \& James, J. M. (2014). Capital Structure and Firm Performance: Evidences from Commercial Banks in Tanzania. Research Journal of Finance and Accounting, 5(14), 168-178.

Kraus, A., \& Litzenberger, R. H. (1973). A state-preference model of optimal financial leverage. The Journal of Finance, 28(4), 911-922. http://dx.doi.org/10.1111/j.1540-6261.1973.tb01415.x

Krishnan, V. S., \& Moyer, R. C. (1997). Performance, capital structure and home country: An analysis of Asian corporations. Global Finance Journal, 8(1), 129-143. http://dx.doi.org/10.1016/S1044-0283(97)90010-7

Lintner, J. (1956). Distribution of incomes of corporations among dividends, retained earnings, and taxes. The American Economic Review, 97-113.

Liu, Y., \& Zhuang, Y. (2009). An empirical analysis on the capital structure of Chinese listed IT companies. International Journal of Business and Management, 4(8), 46. http://dx.doi.org/10.5539/ijbm.v4n8p46

Maksimovic, V., \& Titman, S. (1991). Financial policy and reputation for product quality. Review of Financial Studies, 4(1), 175-200. http://dx.doi.org/10.1093/rfs/4.1.175

Manos, R., Murinde, V., \& Green, C. (2007). Leverage and business groups: Evidence from Indian firms. Journal of Economics and Business, (59), 443-465. http://dx.doi.org/10.1016/j.jeconbus.2007.04.006

Margaritis, D., \& Psillaki, M. (2010). Capital structure, equity ownership and firm performance. Journal of Banking \& Finance, 34(3), 621-632. http://dx.doi.org/10.1016/j.jbankfin.2009.08.023

Michaelas, N., Chittenden, F., \& Poutziouris, P. (1999). Financial policy and capital structure choice in UK SMEs: Empirical evidence from company panel data. Small Business Economics, 12(2), 113-130. http://dx.doi.org/10.1023/A:1008010724051

Milbourn, T. T., Boot, A. W., \& Thakor, A. V. (1999). Megamergers and expanded scope: Theories of bank size and activity diversity. Journal of Banking \& Finance, 23(2), 195-214. http://dx.doi.org/10.1016/S0378-4266(98)00079-X

Miller, M. H. (1977). Debt and Taxes. The Journal of Finance, 32, 261-276.

Miller, S. M., \& Noulas, A. G. (1996). The technical efficiency of large bank production. Journal of Banking \& Finance, 20(3), 495-509. http://dx.doi.org/10.1016/0378-4266(95)00017-8

Mishra, C. S., \& McConaughy, D. L. (1999). Founding family control and capital structure: The risk of loss of control and the aversion to debt. Entrepreneurship theory and practice, 23, 53-64.

Modigliani, F., \& Miller, M. H. (1958). The cost of capital, corporation finance and the theory of investment. The American Economic Review, 261-297.

Modigliani, F., \& Miller, M. H. (1963). Corporate income taxes and the cost of capital: a correction. The American Economic Review, 433-443.

Muritala, T. A. (2012). An Empirical Analysis of Capital Structure on Firms' Performance in Nigeria. International Journal of Advances in Management and Economics, 1(5), 116-124.

Myers, S. (1984). The capital structure puzzle. Journal of Finance, 39(3), 575-592. http://dx.doi.org/10.2307/2327916

Myers, S. C. (1977). Determinants of corporate borrowing. Journal of Financial Economics, 5(2), 147-175. http://dx.doi.org/10.1016/0304-405X(77)90015-0

Myers, S. C., \& Majluf, N. S. (1984). Corporate financing and investment decisions when firms have information that investors do not have. Journal of Financial Economics, 13(2), 187-221. http://dx.doi.org/10.1016/0304-405X(84)90023-0

Nigmonov, A. (2010). Bank performance and efficiency in Uzbekistan. Eurasian Journal of Business and 
Economics, 3(5), 1-25.

Nirajini, A., \& Priya, K. B. (2013). Impact of capital structure on financial performance of the listed trading companies in Sri Lanka. International Journal of Scientific Research Publications, 3(5), 1-9.

Noor, M. A. N. M., \& Ahmad, N. H. B. (2011). Relationship between Islamic banking profitability and determinants of efficiency. IUP Journal of Managerial Economics, 9(3), 43.

Papaa, G., \& Speciale, B. (2011). Financial leverage and managerial compensation: Evidence from the UK. Research in Economics, (65), 36-46. http://dx.doi.org/10.1016/j.rie.2010.03.003

Park, K., \& Jang, S. (2013). Capital structure, free cash flow, diversification and firm performance: A holistic analysis. International Journal of Hospitality Management, (33), 51-63. http://dx.doi.org/10.1016/j.ijhm.2013.01.007

Petersen, M. A., \& Rajan, R. G. (1994). The benefits of lending relationships: Evidence from small business data. The Journal of Finance, 49(1), 3-37. http://dx.doi.org/10.1111/j.1540-6261.1994.tb04418.x

Pratheepkanth, P. (2011). Capital structure and financial performance: Evidence from selected business companies in Colombo stock exchange Sri Lanka. Journal of Arts, Science \& Commerce, 2(2), 171-183.

Pratomo, W. A., \& Ismail, A. G. (2006). Islamic bank performance and capital structure. University Library of Munich, Germany, MPRA,6012.

Rajan, R. G., \& Zingales, L. (1995). What do we know about capital structure? Some evidence from international data. The Journal of Finance, 50(5), 1421-1460. http://dx.doi.org/10.1111/j.1540-6261.1995.tb05184.x

Rajha, K. S., \& Alslehat, Z. A. F. (2014). The Effect of capital structure on the performance of Islamic banks. Interdisciplinary Journal of Contemporary Research in Business, 5(9), 144.

Ramachandran, A., \& Gavoury, C. (2011). The Impact of Capital Structure on Profitability with Special Reference to IT Industry in India. Managing Global Transitions, 9(4), 371-392.

Roden, D. M., \& Lewellen, W. G. (1995). Corporate capital structure decisions: Evidence from leveraged buyouts. Financial Management, 76-87. http://dx.doi.org/10.2307/3665536

Rossi, S. P., Schwaiger, M., \& Winkler, G. (2005). Managerial behavior and cost/profit efficiency in the banking sectors of Central and Eastern European countries. Österreichische Nationalbank. http://dx.doi.org/10.2139/ssrn.676365

Saeedi, A., \& Mahmoodi, I. (2011). Capital Structure and firm performance: Evidence from Iranian companies. International Research Journal of Finance and Economics, 70, 20-29.

Said, D. (2012). Comparing the change in efficiency of the Western and Islamic banking systems. Journal of Money, Investment and Banking, 23, 149-180.

Salawu, R. O. (2009). The Effect of Capital Structure on Profitability: An Empirical Analysis of Listed Firms in Nigeria. International Journal of Business and Finance Research, (3), 121-129.

Salehi, M., \& Biglar, K. (2009). Study of the relationship between capital structure measures and performance: Evidence from Iran. International Journal of Business and Management, 4(1), 97. http://dx.doi.org/10.5539/ijbm.v4n1p97

Salim, M., \& Yadev, R. (2012). Capital structure and firm performance: Evidence from Malaysian listed companies. Social and Behavioral Sciences, 65, 156-166. http://dx.doi.org/10.1016/j.sbspro.2012.11.105

San, T., \& Hang, B. (2011). Capital Structure and Corporate Performance of Malaysian Construction Sector. International Journal of Humanities and Social Science, 1(2), 28-36.

Shlash, A., \& Alouf. (2006). Factors specific to the financial structure of the business projects. Al-Bayt University, $I V(1)$.

Siddiqui, M., \& Shoaib, A. (2011). Measuring performance through capital structure: Evidence from banking sector of Pakistan. African Journal of Business Management, 5(5), 1871-1879.

Siraj, K. K., \& Pillai, P. S. (2012). Comparative study on performance of Islamic banks and conventional banks in GCC region. Journal of Applied Finance \& Banking, 2(3), 123-161.

Soumadi, M., \& Hayajneh, O. (2011). Capital structure and corporate performance: Empirical study on the public Jordanian shareholdings firms listed in the Amman stock market. European Scientific Journal, 8(22), 
173-189.

Srairi, S. A. (2010). Cost and profit efficiency of conventional and Islamic banks in GCC countries. Journal of Productivity Analysis, 34(1), 45-62. http://dx.doi.org/10.1007/s11123-009-0161-7

Staikouras, Ch., \& Wood, G. (2003). The determinants of bank profitability in Europe. European Applied Business Research Conference, Venice, 913.

Stulz, R. (1990). Managerial discretion and optimal financing policies. Journal of financial Economics, 26(1), 3-27. http://dx.doi.org/10.1016/0304-405X(90)90011-N

Sufian, F., \& Habibullah, M. S. (2009). Determinants of bank profitability in a developing economy: Empirical evidence from Bangladesh. Journal of Business Economics and Management, 10(3), 207-217. http://dx.doi.org/10.3846/1611-1699.2009.10.207-217

Taani, K. (2013). Capital Structure Effects on Banking Performance: A Case Study of Jordan. International Journal of Economics, Finance and Management Sciences, 1(5), 227-233. http://dx.doi.org/10.11648/j.jijefm.20130105.13

Tianyu, H. (2013). The comparison of impact from capital structure to corporate performance between Chinese and European listed firms. Master's thesis of Jonkoping University.

Titman, S., \& Wessels, R. (1988). The Determinant of Capital Structure Choice. Journal of Financial, 43(1), 1-19. http://dx.doi.org/10.1111/j.1540-6261.1988.tb02585.x

Toraman, C., Kılıç., Y., \& Reis, Ş. (2013). The Effects of Capital Structure Decisions on Firm Performance: Evidence from Turkey. International Conference on Economic and Social Studies (ICESoS'13), pp. 137-145.

Victor, D., \& Badu, J (2012), Capital Structure and Performance of Listed Banks in Ghana. Global Journal of Human Social Science, 12(5), 56-62.

Wald, J. K. (1999). How Firm Characteristic Affect Capital Structure: An International Comparison. Journal of Financial Research, 22(2), 161-187. http://dx.doi.org/10.1111/j.1475-6803.1999.tb00721.x

Watson, D., \& Head, A. (2007). Corporate Finance, Principles \& Practice (4th ed.). UK: Prentice Hall.

Yudistira, D. (2004). Efficiency in Islamic banking: An empirical analysis of eighteen banks. Islamic Economic Studies, 12(1), 1-19.

\section{Copyrights}

Copyright for this article is retained by the author(s), with first publication rights granted to the journal.

This is an open-access article distributed under the terms and conditions of the Creative Commons Attribution license (http://creativecommons.org/licenses/by/3.0/). 